\title{
Article \\ Effectiveness of Oil-Based Denture Dentifrices-Organoleptic Characteristics, Physicochemical Properties and Antimicrobial Action
}

\author{
Andrezza C. M. dos Santos ${ }^{1}$, Viviane C. Oliveira ${ }^{1,2, * \mathbb{D}}$, Ana P. Macedo ${ }^{1}$, Jairo K. Bastos ${ }^{3}$, Mário S. Ogasawara ${ }^{3}$, \\ Evandro Watanabe ${ }^{2,4}{ }^{\mathbb{D}}$, Isabela M. Chaguri ${ }^{1}$, Cláudia H. Silva-Lovato ${ }^{1}$ and Helena F. O. Paranhos ${ }^{1}$
}

1 Department of Dental Materials and Prosthodontics, School of Dentistry of Ribeirão Preto, University of São Paulo, Café Avenue S/N, Ribeirão Preto 14040-904, SP, Brazil; andrezzamoura@usp.br (A.C.M.d.S.); anapaula@forp.usp.br (A.P.M.); isabelamchaguri@gmail.com (I.M.C.); chl@forp.usp.br (C.H.S.-L.); helenpar@forp.usp.br (H.F.O.P.)

2 Human Exposome and Infectious Diseases Network-HEID, School of Nursing of Ribeirão Preto, University of São Paulo, Bandeirantes Avenue 3900, Ribeirão Preto 14040-904, SP, Brazil; ewatanabe@forp.usp.br

3 Department of Pharmaceutical Sciences, School of Pharmaceutical Sciences of Ribeirão Preto, University of São Paulo, Ribeirão Preto 14040-904, SP, Brazil; jkbastos@fcfrp.usp.br (J.K.B.); ogasa@usp.br (M.S.O.)

4 Department of Restorative Dentistry, School of Dentistry of Ribeirão Preto, University of São Paulo, Ribeirão Preto 14040-904, SP, Brazil

* Correspondence: vivianecassia@usp.br; Tel.: +55-16-3315-4800

Citation: dos Santos, A.C.M.; Oliveira, V.C.; Macedo, A.P.; Bastos, J.K.; Ogasawara, M.S.; Watanabe, E.; Chaguri, I.M.; Silva-Lovato, C.H.; Paranhos, H.F.O. Effectiveness of Oil-Based Denture DentifricesOrganoleptic Characteristics, Physicochemical Properties and Antimicrobial Action. Antibiotics 2021, 10, 813. https://doi.org/10.3390/ antibiotics10070813

Academic Editor: Elena Maria Varoni

Received: 4 June 2021

Accepted: 1 July 2021

Published: 4 July 2021

Publisher's Note: MDPI stays neutral with regard to jurisdictional claims in published maps and institutional affiliations.

Copyright: (c) 2021 by the authors. Licensee MDPI, Basel, Switzerland. This article is an open access article distributed under the terms and conditions of the Creative Commons Attribution (CC BY) license (https:/ / creativecommons.org/licenses/by/ $4.0 /)$.

\begin{abstract}
Denture dentifrices must be effective and not deleterious to prosthetic devices. This study formulated and evaluated dentifrices based on oils of Copaifera officinalis, Eucalyptus citriodora, Melaleuca alternifolia, Pinus strobus, and Ricinus communis. Organoleptic characteristics (appearance, color, odor, taste), physicochemical properties ( $\mathrm{pH}$, density, consistency, rheological, abrasiveness, weight loss, and surface roughness) and antimicrobial (Hole-Plate Diffusion-HPD)/anti-biofilm (Colony Forming Units-CFU) action against Staphylococcus aureus, Streptococcus mutans, and Candida albicans were evaluated. Formulations were compared with water (negative control) and a commercial dentifrice (positive control). The data were analyzed by Kruskal-Wallis and Dunn tests $(\alpha=0.05)$. The organoleptic and physicochemical properties were adequate. All dentifrices promoted weight losses, with high values for $C$. officinalis and $R$. communis, and an increase in surface roughness, without differing from each other. For antimicrobial action, C. officinalis and E. citriodora dentifrices were similar to positive control showing effectiveness against $S$. mutans and $C$. albicans and no dentifrice was effective against $S$. aureus; regarding the anti-biofilm action, the dentifrices were not effective, showing higher CFU counts than positive control for all microorganisms. The dentifrices presented satisfactory properties; and, although they showed antimicrobial action when evaluated by HPD, they showed no effective anti-biofilm action on multispecies biofilm.
\end{abstract}

Keywords: complete denture; acrylic resin; biofilms; denture cleansers; dentifrices; oils; antimicrobial action; adverse effects

\section{Introduction}

Complete denture biofilm is composed of complex microbial communities arising from the association between oral and pathogenic microorganisms [1]. This biofilm must be removed daily, by proper cleaning since it can cause local and systemic diseases. Brushing is widely indicated for denture cleaning and has been considered a simple, inexpensive, and effective method [2-7]. However, the use of adequate dentifrices is essential to avoid adverse effects on prosthetic dental apparatus [8-15], and to ensure antimicrobial effectiveness, as it is one of the main factors that will promote biofilm removal [5,16-21]. Thus, suitable organoleptic and physicochemical properties, along with antimicrobial action, are prerequisites for dentifrices designed specifically for denture hygiene. 
Dentifrices have a complex composition consisting of several agents, each of which have different functions. In addition to the abrasive agent, the disinfectant plays an important role in oral hygiene [17]. For this purpose, the literature has reported the possibility of using herbal products, since they have resulted in enhancing the antimicrobial, anti-biofilm, anti-inflammatory, and antioxidant action of these products [22-27]. Among the natural components used for dental application, antimicrobial activity has been demonstrated by the oils of Bowdichia virgilioides Kunth, Copaifera officinalis, Curcuma longa, Eucalyptus citriodora, Melaleuca alternifolia, Pinus strobus, and Ricinus communis, and these could be used as active principles in cleaning products [28-34]. Consequently, the incorporation of plant extracts into dentifrices has allowed the development of new formulations for oral hygiene, which are effective alternatives to the conventional types available. In vitro studies have evaluated dentifrices for natural teeth based on oils [22] and herbs [23] and have found antimicrobial efficacy against oral microorganisms associated with caries and periodontal disease. Clinical studies have reported that herbal dentifrices [26,27], as well as those containing melaleuca [27], and thymol, eugenol, and eucalyptus [35], oil-based dentifrices reduced the indexes of dental biofilm and gingivitis. As regards dentifrices for denture hygiene, Leite et al. evaluated the antimicrobial activity of $R$. communis-based experimental dentifrices and demonstrated that the formulation at $10 \%$ was efficient against bacteria and fungus, except for S. aureus [20]. Other studies concluded that the same formulation did not cause significant changes in surface roughness and color of artificial teeth [12], and in abrasiveness, hardness and color stability of resilient materials [14,15]. However, studies are still scarce.

Therefore, the aim of this study was to formulate and evaluate dentifrices for denture cleaning based on oils of Copaifera officinalis, Eucalyptus citriodora, Melaleuca alternifolia, Ricinus communis, and Pinus strobus. By means of an in vitro methodology, the following features of the above-mentioned dentifrices were evaluated: organoleptic characteristics (appearance, color, odor, and flavor), physicochemical properties (density, $\mathrm{pH}$, consistency, rheological properties, and abrasiveness) and antimicrobial and anti-biofilm action against Staphylococcus aureus, Streptococcus mutans, and Candida albicans-microorganisms that are frequently present in denture biofilm and have demonstrated potential for pathogenicity [36-41]. The null hypotheses tested were that the experimental dentifrices would have adequate organoleptic and physicochemical properties, and antimicrobial action similar to that of commercial toothpaste, against the microorganisms tested.

\section{Results}

\subsection{Organoleptic Characteristics and Physico-Chemical Properties}

The organoleptic characteristics were classified as "normal" with no changes at the initial time (day 0) and after 15, 30, 60 and 90 days. The physicochemical properties are presented in Table 1 (density, $\mathrm{pH}$, consistency, and rheological characteristics) and Table 2 (abrasiveness-weight loss and surface roughness).

Table 1. Physical-chemical properties of experimental dentifrices.

\begin{tabular}{|c|c|c|c|c|c|c|}
\hline \multirow[b]{2}{*}{ Dentifrice } & \multirow{2}{*}{$\begin{array}{l}\text { Density } \\
\text { (g/mL) }\end{array}$} & \multirow[b]{2}{*}{$\mathrm{pH}$} & \multirow{2}{*}{$\begin{array}{l}\text { Consistency } \\
\text { (mm) }\end{array}$} & \multicolumn{2}{|c|}{ Viscosity } & \multirow[b]{2}{*}{$\begin{array}{c}\text { Hysteresis } \\
\text { Area }\end{array}$} \\
\hline & & & & $\begin{array}{c}\text { Curve } \\
\text { Ascending }\end{array}$ & $\begin{array}{c}\text { Curve } \\
\text { Downward }\end{array}$ & \\
\hline C. officinalis & 1.067 & 7.32 & 89.6 & 3692.58 & $124,222.22$ & 0.66 \\
\hline E. citriodora & 1.111 & 7.36 & 94.0 & 3976.63 & $155,277.78$ & 1.21 \\
\hline R. Communis & 1.116 & 7.36 & 93.4 & 3408.54 & $155,277.78$ & 0.15 \\
\hline M. alternifolia & 1.106 & 7.35 & 89.6 & 3195.50 & $155,277.78$ & 0.97 \\
\hline P. strobus & 1.075 & 7.37 & 81.0 & 3124.49 & $124,222.22$ & 1.74 \\
\hline
\end{tabular}

There were significant differences between the groups for variation in mass and change in surface roughness $(p<0.001)$. When compared with the negative control, all dentifrices (positive control and experiments) promoted weight losses. The lowest mass loss was 
observed for positive control; and the highest mass losses occurred for the C. officinalis $(p<0.001)$ and $R$. communis $(p<0.001)$ dentifrices. All dentifrices were classified as having medium abrasiveness. All dentifrices promoted increase in surface roughness (P. strobus $p<0.001 ;$ M. alternifólia $p=0.001 ; C$. officinalis $p=0.001 ;$ E. citriodora $p=0.002 ; R$. communis $p=0.003$; positive control $p=0.002)$, without differences between them.

Table 2. Descriptive statistics of mass loss $(\mathrm{mg})$, variation in roughness $(\Delta \mathrm{Ra}-\mu \mathrm{m})$ and statistical comparisons.

\begin{tabular}{ccccc}
\hline Properties & Group & Mean \pm SD (Median) & 95\% CI (Range) & $p$ Value \\
\hline & C.a officinalis & $-41.0 \pm 4.1(-41.7)^{\mathrm{d}}$ & $-43.6 ;-38.3(-46.7 ;-34.2)$ & \\
& E. citriodora & $-35.6 \pm 5.2(-36.2)^{\mathrm{cd}}$ & $-38.9 ;-32.3(-42.7 ;-23.6)$ & \\
Mass Loss & R. communis & $-40.3 \pm 5.6(-40.2)^{\mathrm{d}}$ & $-43.9 ;-36.8(-48.1 ;-28.0)$ & $<0.001^{*}$ \\
& M. alternifólia & $-37.2 \pm 3.6(-37 .)^{\mathrm{cd}}$ & $-39.4 ;-34.9(-42.1 ;-29.8)$ & \\
& P. strobus & $-33.3 \pm 4.9(-32.2)^{\mathrm{c}}$ & $-36.4 ;-30.2(-42.2 ;-26.2)$ & \\
& Negative Control & $2.6 \pm 1.1(2.7)^{\mathrm{a}}$ & $1.9 ; 3.3(1.2 ; 4.2)$ & \\
& Positive Control & $-24.3 \pm 5.4(-24.1)^{\mathrm{b}}$ & $-27.7 ;-20.8(-30.7 ;-14.6)$ & \\
\hline \multirow{5}{*}{$\operatorname{Ra}(\mu \mathrm{m})$} & C. officinalis & $3.86 \pm 3.98(1.35)^{\mathrm{b}}$ & $1.33 ; 6.39(0.28 ; 11.37)$ & \\
& E. citriodora & $2.97 \pm 2.75(1.93)^{\mathrm{b}}$ & $1.22 ; 4.72(0.55 ; 9.51)$ & \\
& R. communis & $2.88 \pm 2.03(3.05)^{\mathrm{b}}$ & $1.58 ; 4.17(0.40 ; 5.77)$ & $<0.001$ ** \\
& M. alternifólia & $3.50 \pm 2.99(2.50)^{\mathrm{b}}$ & $1.59 ; 5.40(0.41 ; 8.35)$ & \\
& P. strobus & $5.40 \pm 3.50(5.56)^{\mathrm{b}}$ & $3.18 ; 7.62(1.27 ; 12.41)$ & \\
& Negative Control & $0.01 \pm 0.02(0.01)^{\mathrm{a}}$ & $-0.01 ; 0.02(-0.04 ; 0.04)$ & \\
& Positive Control & $3.17 \pm 2.66(2.69)^{\mathrm{b}}$ & $1.48 ; 4.86(0.52 ; 9.25)$ & \\
\hline
\end{tabular}

SD: Standard deviation; CI-Confidence Interval for Mean; Range (minimum; maximum); Negative Control: brushing without dentifrice (water); Positive Control: Trihydral Commercial toothpaste; * ANOVA; ** KruskalWallis test; ${ }^{\text {abcd }}$ equal letters indicate statistical similarity $(p>0.05)$.

\subsection{Antimicrobial and Anti-Biofilm Activity}

The results of antimicrobial action and anti-biofilm activity are presented in Tables 3 and 4, respectively. Relative to antimicrobial activity, the dentifrices were not effective against $S$. aureus, but showed antimicrobial activity against $S$. mutans and $C$. albicans (Table 3). Significant differences were found between the groups $(p<0.001)$ for both microorganisms. The best results were observed for $C$. officinalis and E. citriodora which showed similar values to those of the positive control (Trihydral) for $S$. mutans ( $p=0.988$; $p=0.110)$ and $C$. albicans $(p=1.000 ; p=1.000)$.

Table 3. Descriptive statistics of inhibition halo $(\mathrm{mm})$ for S. mutans and C. albicans and statistical comparisons.

\begin{tabular}{ccccc}
\hline Microorganisms & Group & $\begin{array}{c}\text { Mean } \pm \text { SD } \\
\text { (Median) }\end{array}$ & $\begin{array}{c}\text { 95\% } \\
\text { CI (Range) }\end{array}$ & $p$ Value * \\
\hline \multirow{5}{*}{ S. mutans } & C. officinalis & $1.3 \pm 0.8(1.8)^{\mathrm{abc}}$ & $0.7 ; 1.9(0.0 ; 1.8)$ & \\
& E. citriodora & $1.5 \pm 0.7(1.9)^{\mathrm{bc}}$ & $0.9 ; 2.0(0.0 ; 1.9)$ & \\
& R. communis & $0.8 \pm 0.4(0.9)^{\mathrm{ab}}$ & $0.4 ; 1.1(0.0 ; 1.2)$ & $<0.001$ \\
& M. alternifólia & $0.3 \pm 0.4(0.0)^{\mathrm{ab}}$ & $0.0 ; 0.6(0.0 ; 0.9)$ & \\
& P. strobus & $0.2 \pm 0.3(0.0)^{\mathrm{a}}$ & $0.0 ; 0.4(0.0 ; 0.8)$ & \\
& Positive Control & $2.7 \pm 0.3(2.6)^{\mathrm{c}}$ & $2.5 ; 2.9(2.4 ; 3.2)$ & \\
\hline \multirow{5}{*}{ C. albicans } & C. officinalis & $1.4 \pm 0.2(1.5)^{\mathrm{bc}}$ & $1.2 ; 1.5(1.0 ; 1.5)$ & \\
& E. citriodora & $1.4 \pm 0.3(1.6)^{\mathrm{c}}$ & $1.2 ; 1.6(0.9 ; 1.6)$ & \\
& R. communis & $1.1 \pm 0.1(1.1)^{\mathrm{ab}}$ & $1.0 ; 1.2(0.9 ; 1.3)$ & $<0.001$ \\
& M. alternifólia & $0.9 \pm 0.2(0.9)^{\mathrm{ab}}$ & $0.7 ; 1.0(0.3 ; 1.1)$ & \\
& P. strobus & $1.0 \pm 0.1(1.0)^{\mathrm{a}}$ & $1.0 ; 1.1(0.9 ; 1.1)$ & \\
& Positive Control & $1.3 \pm 0.1(1.3)^{\mathrm{c}}$ & $1.2 ; 1.4(1.2 ; 1.5)$ & \\
\hline
\end{tabular}

SD: Standard deviation; CI-Confidence Interval for Mean; Range (minimum; maximum); Positive Control: Trihydral Commercial toothpaste; ${ }^{*}$ Kruskal-Wallis test; ${ }^{\text {abc }}$ equal letters indicate statistical similarity $(p>0.05)$.

As regards anti-biofilm activity, significant differences were found between the groups $(p<0.001)$ for all microorganisms. For S. aureus, the positive control showed a higher 
value for reduction in the CFU counts than the experimental groups (C. officinalis $p<0.001$; P. strobus $p<0.001 ;$ M. alternifólia $p<0.001$; E. citriodora $p<0.001 ; R$. communis $p<0.001$ ), with no significant difference from the negative control $(p=0.268)$. For both $S$. mutans and $C$, albicans, no significant difference was found between experimental dentifrices and negative control. For these microorganisms only positive control promoted a reduction in biofilm rates. For $S$. mutans, positive control showed a higher value for reduction in CFU than the negative control $(p<0.001)$ and experimental dentifrices (P. strobus $p<0.001, R$. communis $p<0.001$, M. alternifolia $p<0.001$, C. officinalis $p=0.001$, E. citriodora $p=0.002$ ). These results were also observed for $C$. albicans (negative control $p=0.001 ; C$.a officinalis $p<0.001$; E.citriodora $p<0.001 ; R$. communis $p=0.002 ;$ P. strobus $p=0.027 ;$ M. alternifólia $p=0.028)$.

Table 4. Descriptive statistics of $\log _{10}(\mathrm{CFU}+1)$ for S. mutans, S. aureus and C. albicans and statistical comparisons.

\begin{tabular}{|c|c|c|c|c|}
\hline Microorganisms & Group & Mean \pm SD (Median) & 95\% CI (Range) & $p$ Value * \\
\hline \multirow{7}{*}{ S. mutans } & C. officinalis & $4.56 \pm 0.82(4.69)^{b}$ & $4.15 ; 4.96(2.60 ; 5.72)$ & \multirow{7}{*}{$<0.001$} \\
\hline & E. citriodora & $4.46 \pm 0.99(4.53)^{b}$ & $3.97 ; 4.95(1.61 ; 6.06)$ & \\
\hline & R. communis & $5.12 \pm 0.77(5.27)^{b}$ & $4.74 ; 5.50(3.60 ; 6.56)$ & \\
\hline & M. alternifólia & $4.88 \pm 0.62(4.92)^{b}$ & $4.57 ; 5.19(3.90 ; 5.91)$ & \\
\hline & P. strobus & $5.24 \pm 0.74(5.48)^{b}$ & $4.88 ; 5.61(3.60 ; 6.48)$ & \\
\hline & Negative Control & $5.06 \pm 0.52(5.06)^{b}$ & $4.81 ; 5.31(4.01 ; 5.97)$ & \\
\hline & Positive Control & $0.60 \pm 1.20(0.00)^{\mathrm{a}}$ & $0.00 ; 1.20(0.00 ; 3.64)$ & \\
\hline \multirow{7}{*}{ S. aureus } & C. officinalis & $6.20 \pm 0.74(6.38)^{c}$ & $5.83 ; 6.56(4.45 ; 7.08)$ & \multirow{7}{*}{$<0.001$} \\
\hline & E. citriodora & $6.09 \pm 0.88(6.14) b c$ & $5.65 ; 6.53(3.66 ; 7.93)$ & \\
\hline & R. communis & $5.92 \pm 0.56(5.96)^{b c}$ & $5.64 ; 6.19(4.60 ; 6.63)$ & \\
\hline & M. alternifólia & $6.20 \pm 0.54(6.08)^{c}$ & $5.93 ; 6.46(5.30 ; 7.08)$ & \\
\hline & P. strobus & $6.20 \pm 0.53(6.34)^{c}$ & $5.94 ; 6.46(4.71 ; 6.91)$ & \\
\hline & Negative Control & $5.48 \pm 0.47(5.49)^{a b}$ & $5.26 ; 5.71(4.72 ; 6.46)$ & \\
\hline & Positive Control & $3.50 \pm 1.21(3.39)^{a}$ & $2.90 ; 4.10(1.61 ; 6.03)$ & \\
\hline \multirow{7}{*}{ C. albicans } & C. officinalis & $3.29 \pm 0.48(3.34)^{b}$ & $3.05 ; 3.53(2.08 ; 4.17)$ & \multirow{7}{*}{$<0.001$} \\
\hline & E. citriodora & $3.00 \pm 0.43(2.89)^{b}$ & $2.79 ; 3.21(2.30 ; 3.77)$ & \\
\hline & R. communis & $2.90 \pm 0.54(2.92)^{b}$ & $2.63 ; 3.17(2.08 ; 4.09)$ & \\
\hline & M. alternifólia & $2.73 \pm 0.41(2.77)^{b}$ & $2.53 ; 2.93(1.91 ; 3.41)$ & \\
\hline & P. strobus & $2.58 \pm 0.87(2.76)^{b}$ & $2.15 ; 3.01(0.00 ; 3.73)$ & \\
\hline & Negative Control & $2.83 \pm 0.68(2.90)^{b}$ & $2.50 ; 3.16(1.61 ; 3.60)$ & \\
\hline & Positive Control & $1.47 \pm 1.03(1.61)^{\mathrm{a}}$ & $0.96 ; 1.98(0.00 ; 2.95)$ & \\
\hline
\end{tabular}

SD: Standard deviation; CI-Confidence Interval for Mean; Range (minimum; maximum); Negative Control: brushing without dentifrice (water); Positive Control: Trihydral Commercial toothpaste; ${ }^{*}$ Kruskal-Wallis test; ${ }^{\text {abc }}$ equal letters indicate statistical similarity $(p>0.05)$.

\section{Discussion}

In this study, dentifrices were formulated and evaluated with the aim of obtaining an effective and safe product. The microorganisms selected were those related to denture biofilm and played an important role in the development of oral pathologies [1] Furthermore, Trihydral toothpaste (positive control) was used because it is indicated for natural teeth and prosthetic devices and has been shown to be effective against denture biofilm $[17,18,20]$. The null hypotheses were partially accepted, since all experimental dentifrices exhibited adequate organoleptic characteristics and satisfactory physico-chemical properties, but not all showed antimicrobial effectiveness against the microorganisms evaluated.

The results showed adequate organoleptic characteristics and no subsequent changes The physicochemical properties indicated that the dentifrices were suitable for use to clean dentures. The data found for density and consistency were within acceptable values for dentifrices $[16,17]$. The $\mathrm{pH}$ values $(>7)$ showed the characteristic of neutral products and were within the range of 4.5 and 10.5, considered suitable for dentifrices. An acidic $\mathrm{pH}$ influences the viscosity and action of active principles $[16,17]$. Therefore, the results were 
favorable, because they allowed for a balanced oral $\mathrm{pH}$, contributing to the maintenance of oral health, in addition to preventing damage to denture base acrylic resin. Relative to the rheological properties, the dentifrices showed low viscosity that could be considered suitable for denture dentifrices. The values obtained for the hysteresis area showed both moderate degree of thixotropy and rate of active principle release. This characteristic reflects the spreading power of the product and ensures good conditions of use and release of the active principle [17]. The yield value is defined by the shear stress, which is found in the rheogram graph, and allows the fluidity of the product to be defined. This datum is important relative to products recommended for denture cleaning, as it allows the product to be released from the storage tube with adequate viscosity and flow for use.

Highly abrasive dentifrices should not be used, as they can cause excessive wear and an increase in surface roughness of acrylic resin, making it difficult to remove biofilm [8-16]. All of the experimental dentifrices caused mass loss and were classified as having medium abrasiveness. The classification used is related to two years of simulated brushing with a brushing machine $[10,11,13,42]$. Therefore, the values obtained could be considered satisfactory, since a medium abrasiveness was obtained in a simulated brushing cycle of five years. Abrasive silica (Tixosil 73) has highly water-soluble particles and has low abrasive characteristics [17]. However, its association with the silica thickener (Tisoxil 43B) may lead to a small increase in abrasive action since there is interaction between the particles of both agents, with changes in consistency, and consequently, in the degree of abrasiveness $[8,9]$. The highest mass loss values observed for $C$. officinalis and $R$. communis dentifrices could be attributed to the oils since there were no other differences between the formulations. All dentifrices changed the surface roughness of the acrylic resin. These results agreed with the findings of previous studies that showed an increase in acrylic resin roughness with the use of brushing [8-13]. Therefore, brushing time may be the factor that influenced the magnitude of the values obtained.

Determination of the Minimal Inhibitory Concentration (MIC) by means of the broth microdilution method is frequently used for initial screening of antimicrobial activity. The results indicated that five oils had strong antimicrobial action against the microorganisms evaluated. Nonetheless, it is worth mentioning that this assay is not widely indicated for testing compounds of a lipophilic nature and other hydrophobic extracts because these compounds are incapable of completely diffusing in aqueous media [43]. Consequently, it has been suggested that the antimicrobial or anti-biofilm activity should be confirmed using additional assays. Therefore, in the present study, the capacity of the dentifrices for inhibiting microbial growth (Hole-Plate Diffusion) and removing mature biofilm from denture base acrylic resin specimens was assessed.

The denture biofilm is a complex community with an extremely variable composition $[38,39]$. The antimicrobial action of dentifrices was evaluated against microorganisms with potential for pathogenicity, commonly present in the oral microbiota and that has been isolated from the internal surface of complete dentures $[19,36,37,39,40]$. C. albicans, the most prevalent fungus in the human oral cavity, has been shown to be the primary cause of denture-related stomatitis [44-50]. S. mutans is responsible for consolidation and progression of dental biofilm, initial colonization of prosthetic surfaces, and its antigens have been related to denture-related stomatitis [51,52]. S. aureus is related to systemic infections, such as septicemia, endocarditis, pneumonia and abscesses [51,53,54], and to local diseases such as angular cheilitis, endodontic infections and mucositis $[55,56]$.

With specific regard to $S$. aureus, taken as a whole, neither the antimicrobial nor the anti-biofilm evaluation indicated satisfactory results, a finding that was in disagreement with MIC results. The hole-plate diffusion assay has limitations due to the volatility, insolubility and irregular diffusion of oils [21]. This limitation could explain the variations in the antimicrobial results. Moreover, the literature has pointed that the susceptibility of microorganisms in states both associated and not associated with biofilm, is widely discrepant. The tolerance of biofilm to antimicrobial agents is about 100-1000 times greater when compared with that of the planktonic form [57]. This statement could explain the 
absence of anti-biofilm activity, therefore, formulations with high oil concentration might produce better results.

Studies have shown that $S$. aureus is resistant to the action of denture cleansers $[54,58]$. Whereas for yeasts, the expression of virulence factors and resistance genes may explain the complexity of controlling this microorganism [59]. The association of different active ingredients in peroxide solutions, such as potassium monopersulfate, sodium lauryl sulfate and titanium dioxide have been shown to enhance the antimicrobial action against this strain [60-62]. Likewise, the presence of sodium monofluorophosphate in a conventional dentifrice has been shown to act by inhibiting the enzymatic metabolism and adherence of this bacteria, and providing an antimicrobial effect $[20,21]$. According to the authors, the dentifrices may have interfered in the bacteria adhesion to the substrate and in organization of a polysaccharide matrix since the presence of surfactants and agents with antibiofilm activity can interfere in the surface tension of the substrate.

The antimicrobial findings regarding $S$. mutans and $C$. albicans indicated that the dentifrices showed eminent action, with better results for C. officinalis and E. citriodora. C. officinalis oil is considered an antibacterial agent against Gram-positive and Gram-negative pathogens present in the oral cavity $[63,64]$, which makes it a promising substance with possibilities for the development of various oral care formulations [34,65]. This antimicrobial action may be attibutet to $\beta$-caryophyllene, the main bioactive constituent $(58.7 \%)$ that alters membrane permeability and cell integrity, leading to membrane damage and intracellular content leakage [66]. E. citriodora oil has antimicrobial potential [67,68], and has been used in dental products [69]. Luqman et al. evaluated its action against several microorganisms and showed that this oil had more effective action against Gram-positive bacteria when compared with the Gram-negative types [31]. The eucalyptol, which accounted for approximately $79.5 \%$ of the E. citriodora oil, may be the responsible for this action, due to alteration on permeability and function of cell membrane leading to intracellular content leakage [70]. A low level of antimicrobial action of the M. alternifolia and R. communis dentifrices was also observed. The M. alternifolia oil has many applications in dentistry due its capacity for promoting alterations in the membrane permeability of yeast, consequently damaging the mitochondrial membrane, leading to cell death [24,30]. This mechanism of action is associated with the bioactive constituent terpinen-4-ol, which acts mainly on the cell membranes and organelles [71]. The antimicrobial action of $R$. communis oil is attributed to the toxicity of the protein ricin that inhibits the protein synthesis [72]. Solutions obtained from esterification of this oil have demonstrated moderate action against denture biofilm [40]; however, the full description of its mechanism of action has not yet been reported. The smallest halos were found for P. strobus dentifrice. Studies on Strobus species are scarce and its mechanism of action is not completely known. It has been suggested that its fungicidal action is related to high concentrations of hydrocarbon monoterpenes [29]. On this subject, $\alpha$-pinene and $\beta$-pinene have been associated with important antimicrobial and antibiofilm actions [73]. Although promising antimicrobial action could be observed, the experimental dentifrices did not differ from the negative control and showed higher CFU counts than the positive control, without differing from each other. These results did not provide strong evidence that the bioactive constituents would improve the antibiofilm activity of oil-based dentifrices. Indeed, the variability in chemical composition of the oils is highly varied and the scientific literature is not conclusive about biological activities of all components. The effectiveness of Trihydral toothpaste is attributed to the presence of chloramine-T, an active ingredient capable of promoting oxidation and protein hydrolysis reactions $[17,18,20]$. In fact, the similarities between the values found for the negative control (brushing with water) and experimental groups could be explained by the force exerted by the mechanical brushing which even without dentifrice, acted by removing the biofilm.

Association of a toothbrush with a dentifrice is the most frequently used denture cleaning method [6,7]. However, further studies are still needed, since dentifrices for dentures have shown effective biofilm removal $[2-5,16]$, but only moderate antimicrobial 
action $[16,17,19,20]$. Although natural products have been used in conventional dentifrices $[22-24,26,27]$, their use in dentifrices for denture cleaning has not been widely reported.

Future studies should evaluate the effect of different associations between thickener, abrasive agents, and the proportion of humectant, in order to obtain formulations with a higher level of consistency and lower degree of abrasiveness. Furthermore, future analysis should consider the development of new formulations of dentifrices with increased oil concentration. This matter could clarify whether the absence of anti-biofilm activity could be associated with low oil availability. The present study was limited by the fact that the antimicrobial action was evaluated and observed against only one biofilm model composed of S. aureus, S. mutans and C. albicans. It is important to develop future studies with other microorganisms commonly found in the prosthetic biofilm. These formulations should also be tested in randomized clinical trials, in order to evaluate the factors related to the brushing process, and their efficacy against in vivo biofilm. These studies must include the use of a placebo dentifrice without an active ingredient, in order to allow evaluation of the action of the other constituents of the formulation, in an attempt to more clearly elucidate the antimicrobial action of the oils used.

\section{Materials and Methods}

\subsection{Essential Oils and Fatty Acids}

Oils were obtained from rhizomes, leaves, seeds or stems by steam distillation or cold pressing and their chemical compositions were determined by gas chromatography (Table 5).

Table 5. Chemical characterization of the oils.

\begin{tabular}{|c|c|c|c|}
\hline Oils & Source & Manufacturer & Chemical Constituents * \\
\hline C. officinalis & Stems & Oshadhi Brazil & $\begin{array}{c}\text { Essential oil: } \beta \text {-caryophyllene }(58.73 \%) ; \alpha \text {-humulene }(7.81 \%) ; \alpha \text {-bergamothene } \\
(4.96 \%) ; \alpha \text {-copaene }(4.66 \%) ; \text { Germacrene }(4.30 \%) ; \Delta \text {-cadinene }(2.19 \%) ; \beta \text {-selinene } \\
(1.73 \%) ; \beta \text {-elemene }(1.56 \%) ; \alpha \text {-cubebene }(0.56 \%) .\end{array}$ \\
\hline E. citriodora & Leaves & $\begin{array}{l}\text { Sítio das } \\
\text { Melaleucas, } \\
\text { Ibiuna, SP, Brazil }\end{array}$ & $\begin{array}{l}\text { Essential oil: Eucalyptol (79.53\%); trans- } \beta \text {-ocimene }(14.86 \%) ; \text { o-cymene }(1.57 \%) ; \\
\text { 6,6-dimethyl-2-methylene }(1.06 \%) ; \alpha \text {-terpineol }(0.66 \%) ; \\
\text { 4-methyl-1-(1-methylethyl) }(0.57 \%) ; \alpha \text {-pinene oxyde }(0.49) ; 6 \text {-octenal }(0.47 \%) ; \\
\text { (R)- } \alpha \text {-terpinyl acetate }(0.42) ; \beta \text {-myrcene }(0.36 \%) \text {. }\end{array}$ \\
\hline M. alternifolia & Leaves & $\begin{array}{l}\text { Sítio das } \\
\text { Melaleucas }\end{array}$ & $\begin{array}{l}\text { Essential oil: Terpinen-4-ol (32.1\%); y-terpinene }(22.6 \%) ; \alpha \text {-terpinene }(11.00 \%) ; \\
\text { terpinolene }(4.00 \%) ; \alpha \text {-pinene }(2.80 \%) ; \text { viridiflorol }(2.80 \%) ; \alpha \text {-terpineol }(2.50 \%) ; \\
\text { 1,8-cineole }(2.4 \%) ; \beta \text {-gurjunene }(2.10 \%) \text {; limonene }(1.80 \%) \text {; p-cymene }(2.20 \%) ; \\
\text { myrcene }(0.9 \%) ; \alpha \text {-thujene }(1.10 \%) ; \beta \text {-pinene }(0.90 \%) ; \text { sabinene }(0.90 \%)\end{array}$ \\
\hline P. strobus & Leaves & Oshadhi Brazil & $\begin{array}{l}\text { Essential oil: } \alpha \text {-pinene }(33.02 \%) ; \beta \text {-pinene }(30.41 \%) \text {; myrcene }(9.19 \%) ; \text { limonene } \\
(9.16 \%) ; \Delta 3 \text {-carene }(6.39 \%) ; \text { caryophyllene }(4.52 \%) \text {; terpinolene }(1.24 \%) \text {; bornyl } \\
\text { acetate }(1.02 \%) ; \beta \text {-caryophyllene }(0.62 \%) ; \alpha \text {-terpineol }(0.57 \%) ; \alpha \text {-Humulene } \\
\quad(0.27 \%) ; \text { bornyl }(0.25 \%) ; \delta \text {-cadinene }(0.25) \text {; Terpinen- } 4 \text {-ol }(0.20) .\end{array}$ \\
\hline R. communis & Seeds & Laszlo Group & $\begin{array}{c}\text { Fatty acids: C18:1OH-ricinoleic }(84.10 \%) \text {; C18:2-linoleic }(4.60 \%) \text {; C18:1-oleic } \\
(3.60 \%) ; \text { C16:0-palmitic }(1.30 \%) ; \text { C18:0-stearic }(1.10 \%) \text {; C18:3-linolenic }(0.60 \%) \text {; } \\
\text { C22:0-behenic }(0.60 \%) \text {; C20:0-arachidic }(0.50 \%) \text {. }\end{array}$ \\
\hline
\end{tabular}

* According to manufacturer's information.

\subsection{Strains and Inoculum Preparation}

Minus $80^{\circ} \mathrm{C}$ glycerol stocks of Streptococcus mutans (ATCC 25175), Staphylococcys aureus (ATCC 25923) and Candida albicans (ATCC 10231) strains were thawed and streaked out on agar surface (S. mutans: Brain Heart Infusion-BHI (Kasvi, São José dos Pinhais, Paraná, Brazil); S. aureus: Tryptic Soy-TS (Kasvi); C. albicans: Sabouraud Dextrose-SD (Kasvi)). S. aureus and C. albicans plates were incubated at $37^{\circ} \mathrm{C}$ for $24 \mathrm{~h}$ under aerobic conditions while $S$. mutans plates were incubated under microaerophilic conditions. Subsequently, one colony was transferred into $15 \mathrm{~mL}$ of broth medium and re-incubated at $37^{\circ} \mathrm{C}$ for $19-24 \mathrm{~h}$ 
in order to obtain cells in an exponential growth phase. Then, the culture was centrifuged (Eppendorf, Hamburg, Germany) at $4200 \mathrm{~g}$ for $5 \mathrm{~min}$ and washed twice in phosphate buffered saline (PBS). The bacteria concentration per milliliter of PBS was determined by reading the optical density (OD) in a spectrophotometer (Thermo Scientific, Waltham, MA, USA), at the wavelength of $625 \mathrm{~nm}$. Yeast cells were counted in a Neubauer chamber (HBG Company, Giessen, Germany).

\subsection{Determination of Minimum Inhibitory Concentration (MIC)}

For antimicrobial activity screening, the minimum inhibitory concentration (MIC) of the seven oils was determined by the broth microdilution method according to the Clinical and Laboratory Standards Institutes [74]. Five percent solutions were initially prepared in $5 \%$ (v/v) of dimethylsulfoxide (DMSO) (Sigma Aldrich, San Luis, MO, USA). Subsequently, two-fold serial dilutons of the oil-containing solutions were made in culture broths (BHI, TS and SD), in order to produce ten oil concentrations, ranging from 2.5 to $0.0048 \%(\mathrm{v} / \mathrm{v})$. One hundred microliters of each concentration were placed into 96-well plates, in duplicate, (TPP, Trasadingen, Switzerland). Then, $10 \mu \mathrm{L}$ of microorganism suspension $\left(10^{7} \mathrm{CFU} / \mathrm{mL}\right.$ for bacteria; $10^{5} \mathrm{CFU} / \mathrm{mL}$ for yeast) were added to each serial dilution and incubated at $37^{\circ} \mathrm{C}$ for $24 \mathrm{~h}$. Positive control and negative controls, respectively, were obtained by adding, or not adding the standardized microbial inoculum to culture medium without oil supplement. An additional control with two-fold serial dilutions of DMSO were prepared in order to verify the effect of the diluent on inhibiting the microorganism growth.

Microbial growth was evaluated by turbidity or absence of turbidity the culture medium. The MIC was determined as being the lowest concentration of the oil or DMSO to result in no microbial growth (Table 6).

Table 6. Minimum Inhibitory Concentration (MIC) of oils against S. aureus, S. mutans and C. albicans.

\begin{tabular}{cccccccc}
\hline \multicolumn{7}{c}{ Minimum Inhibitory Concentration (\%) } \\
\hline Microorganisms & B. virgilioides Kunth & C. officinalis & C. Longa & E. citriodora & R. Communis & M. alternifolia & P. strobus \\
\hline S. aureus & $>2.5$ & $<0.009$ & 2.5 & 0.62 & $<0.009$ & $<0.009$ & $<0.009$ \\
S. mutans & $>2.5$ & 0.0048 & 1.25 & 0.62 & 0.078 & 0.078 & 0.009 \\
C. albicans & $>2.5$ & $>2.5$ & $>2.5$ & 0.62 & $>2.5$ & 0.62 & $>2.5$ \\
\hline
\end{tabular}

To confirm growth inhibition, $20 \mu \mathrm{L}$ of the suspension from each well were dropped onto a BHI, TS and SD agar surface. Microbial inhibition was categorized as strong (MIC $<0.5 \mathrm{mg} / \mathrm{mL})$, moderate $(0.5 \leq \mathrm{MIC} \leq 1.5 \mathrm{mg} / \mathrm{mL})$, and weak (MIC $>1.5 \mathrm{mg} / \mathrm{mL})$ as previously reported [75].

The C. officinalis, E. citriodora, R. communis, M. alternifólia and P. strobus oils promoted strong growth inhibition of $S$. aureus and S. mutans. The E. citriodora and M. alternifólia essential oils promoted strong growth inhibition of $C$. albicans. Since these oils presented relevant antimicrobial activity, they were selected for the formulation of experimental dentifrices.

\subsection{Dentifrice Formulations}

Five formulations of dentifrices at final concentrations of $0.5 \%(\mathrm{v} / \mathrm{v})$ of the oils were obtained. This concentration was used because it was considered feasible to obtain adequate formulations relative to the organoleptic characteristics, physicochemical properties and antimicrobial action. The dentifrices were prepared according to previously mentioned methodology [20]. Briefly, hydroxyethyl cellulose, glycerin, EDTA, saccharin sodium, and water were homogenized and kept at rest until gel formation. After this, the other components were added and mixed with the gel. After obtaining a homogeneous dentifrice, it was dispensed and stored in appropriated tubes. The dentifrice compositions are presented in Table 7. 
Table 7. Basic composition of experimental dentifrices.

\begin{tabular}{ccc}
\hline Components & Manufacturer & Function \\
\hline Hydroxyethylcellulose & $\begin{array}{c}\text { Fagron Rubber Industry Products Ltd.a, } \\
\text { Guarulhos, SP, Brazil }\end{array}$ & Thickener \\
Glycerin & Ely Martins, Ribeirão Preto, SP, Brazil \\
EDTA & Fagron P Rubber Industry Products Ltd.a, \\
Guarulhos, SP, Brazil & Humectant \\
Sodium benzoate & Labsynth Ltd.a, Diadema, São Paulo, SP, & Chelating Agent \\
Cocamidopropyl & Fagron Rubber Industry Products Ltd.a, & Preservative \\
betaine & Guarulhos, SP, Brazil & Surfactant \\
Oils & Laszo Group & \\
Silica (Tisoxil 73) & Sítio das Melaleucas & Antimicrobial active \\
Silica (Tisoxil 43 B) & Rhodia Solvay Group, São Paulo, SP, Brazil & Abrasive \\
Titanium dioxide & Fagron Rubber Industry Products Ltd.a, & Thickener \\
Menthol aroma & Guarulhos, SP, Brazil & Pigment (white) \\
Distilled water & Givaudan of Brazil Ltd.a, São Paulo, SP, Brazil & Flavoring \\
\hline
\end{tabular}

\subsection{Organoleptic Characteristics and Physico-Chemical Properties}

After the dentifrices were obtained, the organoleptic characteristics were evaluated in time intervals of $15,30,60$, and 90 days after their initial assessment [20]. The dentifrices were stored in white enameled aluminum tubes, protected in a humidity-free space and away from temperature variations. The appearance and color were observed by the visual method. Odor and taste were evaluated by olfactory and gustative methods. The odor and flavor analyses were performed considering a menthol-flavored product. Appearance was classified according to the criteria: I) Normal, II) Slightly separated, III) Separated. Color, odor and taste were classified according to the criteria: I) Normal, II) Slightly modified, III) Modified and IV) Intensely modified.

The physicochemical properties were evaluated in accordance with previous methodology [17]. The density was obtained by the equation $d=m / v$, where " $d$ " is density, " $m$ " is the measured mass and " $v$ " the volume. Hydrogenionic potential was measured with a pHmeter (Digimed DM20; Digicrom Analytical Ltd.a., São Paulo, São Paulo, Brazil). Consistency was verified by the spreadability method, based on the sample flow under constant load in a pre-determined time interval. Rheological features were determined using a rheometer (Rheotest 2.0; VEB MLW Prufgerate-Werk Medingen, Sitz Freital, Germany). Abrasiveness was determined by evaluating the variation in mass, and surface roughness by the change in heat-polymerized acrylic resin specimens $(90 \mathrm{~mm} \times 30 \mathrm{~mm} \times$ $3 \mathrm{~mm}$; Clássico Produtos Odontológicos Ltd.a., São Paulo, SP, Brazil; $n=84$ ) after simulated artificial brushing performed by a machine (Mavtec, Ribeirão Preto, SP, Brazil), in accordance with ISO/DTS 145691 specifications for wear testing [42]. The specimens were distributed ( $n=12)$ into groups: brushing without dentifrice (only distilled water-23 \pm $3{ }^{\circ} \mathrm{C}$ ) (Negative Control) and six dentifrices-five experimental types (oils) and one commercial (Positive Control) (Trihydral-Perland Pharmacos, Cornelio Procópio, PR, Brazil). The machine worked at a rate of $356 \mathrm{rpm}$, under a $200 \mathrm{~g}$ load and a linear cleaning movement length of $3.8 \mathrm{~cm}$. Each specimen received $10 \mathrm{~mL}$ of the suspension (distilled water or dentifrice diluted in distilled water at ratio of 1:1) and was brushed with soft toothbrushes (Tek; Johnson \& Johnson, São José dos Campos, São Paulo, Brazil). The brushing time was $250 \mathrm{~min}(89,000$ cycles), corresponding to five years of simulated exposure to brushing [10]. Suspensions and brushes were replaced at each time interval of 50 and $100 \mathrm{~min}$, respectively. Before and after the test, the specimens were weighed and the variation in mass (mg) was obtained, and classified as: low (values up to $24 \mathrm{mg}$ ); medium (from 25 to $45 \mathrm{mg}$ ) and high (values over $46 \mathrm{mg}$ ) [10]. The surface roughness measurements were also obtained $(\mu \mathrm{m}$; 
three readings of $4.0 \mathrm{~mm}$ long, $0.8 \mathrm{~mm}$ cut-off and at $0.5 \mathrm{~mm} / \mathrm{s}$ ) by means of a roughness tester (Surftest SJ-201P, Mitutoyo Corporation, Kawasaki, Japan). The arithmetic average of the three measurements was calculated.

\subsection{Antimicrobial and Anti-Biofilm Activity}

The antimicrobial activity was estimated by measuring zones of inhibition by the hole-plate diffusion method (HPD) [22] against S. mutans, S. aureus, and C. albicans. In parallel, the anti-biofilm activity was assessed against a model of multispecies biofilms, composed of the same microorganisms [62,76] and in accordance with Paranhos et al. [61]. The assays were conducted in three different time intervals.

For the hole-plate diffusion method, agar culture media (BHI, TS an SD) were prepared, sterilized and dispensed into $90 \mathrm{~mm}^{2}$ sterile Petri dishes to provide a base layer of $8 \mathrm{~mL}$. Microbial inoculums with $10^{6} \mathrm{CFU} / \mathrm{mL}$ of each microorganism were added to aliquots of $12 \mathrm{~mL}$ culture media $\left(45^{\circ} \mathrm{C}\right)$. The suspensions obtained were deposited onto a base layer. After gelation, plastic straws were used to make three holes measuring $5.0 \mathrm{~mm}$ in diameter in each Petri dish. These holes received $\sim 20 \mu \mathrm{L}$ of each of the 06 dentifrices. The Petri dishes were pre-incubated at ambient temperature $\left(25^{\circ} \mathrm{C}\right)$ for $2 \mathrm{~h}$, to allow the product to diffuse into the culture medium. After the pre-incubation period had elapsed, the Petri dishes were incubated in a microbiological oven at $37^{\circ} \mathrm{C}$ for $24 \mathrm{~h}$. The microbial growth inhibition halos that formed around the dentifrices were measured with the aid of a millimeter ruler, at three different points. in order to obtain a mean value. The measurements $(\mathrm{mm})$ were made at the longest distance between two points, (from the outer limit of the inhibition zone to the hole). As this test was performed in triplicate, at three different time intervals, nine halos were obtained, and consequently, 9 measurements for each microorganism.

For anti-biofilm activity, 126 specimens $(15 \times 3 \mathrm{~mm})$ of heat-polymerized acrylic resin (Clássico, Artigos Odontológicos Ltd.a., São Paulo, São Paulo, Brazil) were sterilized by means of microwave irradiation (650 W, $6 \mathrm{~min}$ ) [60-62] and randomly distributed in 24-well tissue culture plates (TPP). Each well received $2 \mathrm{~mL}$ of BHI Broth (BHIB) inoculated with $10^{6} \mathrm{CFU} / \mathrm{mL}$ of $\mathrm{C}$. albicans and $10^{7} \mathrm{CFU} / \mathrm{mL}$ of $S$. aureus and S. mutans. The plates were incubated at $37{ }^{\circ} \mathrm{C}$ for $90 \mathrm{~min}$, at $75 \mathrm{rpm}$, under microaerophilic conditions (adhesion period). After this, each specimen was washed twice with PBS to remove non-adherent microorganisms. To promote biofilm growth and maturation, $2 \mathrm{~mL}$ of fresh BHIB was added to each well. Then, the plates were incubated at $37^{\circ} \mathrm{C}$ for $48 \mathrm{~h}$, at $75 \mathrm{rpm}$, under microaerophilic conditions. With the aim of confirming asepsis of the procedures, two specimens were not inoculated, and received only sterile culture media. Afterwards, specimens were distributed $(n=18)$ into the seven groups previously described and submitted to mechanical brushing. The specimens were fixed in sterile polymethyl methacrylate plates (Plexiglass; Day Brazil, Ribeirão Preto, São Paulo, Brazil), and brushed with the dentifrices in an artificial brushing machine, as previously described, for $3 \mathrm{~min}$. (16.2 cycles), corresponding to three daily brushing events of one minute. After this, each specimen was aseptically removed, washed three times with PBS and transferred to tubes with $10 \mathrm{~mL}$ of Letheen broth (BD Difco, Sparks, MN, USA). After sonication (200 W; $40 \mathrm{KHz}$ (Altsonic, Ribeirão Preto, São Paulo, Brazil) for $20 \mathrm{~min}$, serial dilutions $\left(10^{-1}\right.$ to $\left.10^{-4}\right)$ of the resultant suspension were seeded onto Petri dishes containing selective culture medium [S. mutans: Mitis Salivarius Agar (HiMedia, Mumbai, India) supplemented with $100 \mathrm{U} / \mathrm{mL}$ of Nystatin (Sigma Aldrich, Saint Louis, MO, USA), $0.2 \mathrm{U} / \mathrm{mL}$ of Bacitracin (Sigma Aldrich) and 20\% (w/v) of sucrose (Dinâmica, Indaiatuba, SP, Brazil); S. aureus: Mannitol Salt Agar (Kasvi) supplemented with $100 \mathrm{U} / \mathrm{mL}$ of Nystatin; C. albicans: Sabouraud Dextrose Agar (Kasvi) supplemented with $0.05 \mathrm{~g} / \mathrm{L}$ cloranfenicol (Sigma)]. Then, the Plates were incubated in a microbiological incubator at $37^{\circ} \mathrm{C}$ for $48 \mathrm{~h}$. S. mutans plates were incubated under microaerophilic conditions. After the incubation period, the number of colonies was counted, the value of colony forming units (CFUs) was obtained and transformed to $\log _{10}(\mathrm{CFU}+1)$. 


\subsection{Statistical Analysis}

The organoleptic characteristics were presented by descriptive analysis. Values relative to density, $\mathrm{pH}$, consistency, viscosity and hysteresis area are presented in Table. After assumption of non-normal distribution (Shapiro-Wilk test) and non-homogeneous variances (Levene test), the data involving abrasiveness and antimicrobial action were submitted to the Kruskal-Wallis followed by the Dunn post-hoc test with Bonferroni adjustment $(\alpha=0.05)$. All statistical tests were performed by a blinded researcher using the IBM SPSS Statistics for Windows 21.0 software (IBM Corp.).

\section{Conclusions}

Based on the methodology used and the results obtained, within the limitations of this study, it was concluded that the experimental oil-based denture dentifrices presented satisfactory organoleptic and physicochemical properties. Nonetheless, the results clearly illustrated that none of the dentifrices evaluated was capable of significantly reducing the multispecies biofilm viability.

Author Contributions: Conceptualization, A.C.M.d.S. and H.F.O.P.; data curation, A.C.M.d.S. and I.M.C.; formal analysis, A.P.M.; funding acquisition, H.F.O.P.; investigation, A.C.M.d.S. and I.M.C.; methodology, V.C.O., A.P.M. and M.S.O.; project administration, H.F.O.P.; supervision, C.H.S.-L.; validation, H.F.O.P., J.K.B. and E.W.; visualization, J.K.B., E.W. and M.S.O.; writing-original draft, V.C.O. and A.P.M.; writing-review and editing, A.C.M.d.S. and H.F.O.P. All authors have read and agreed to the published version of the manuscript.

Funding: This work was supported by the São Paulo Research Foundation-FAPESP (Grant Number: 2019/02404-8) and by Coordination for the Improvement of Higher Education Personnel-CAPES (Finance Code 001).

Acknowledgments: The authors thank Cunha RAS (Sítio das Melaleucas, Ibiúna, SP, Brazil) for providing the Melaleuca alternifolia and Eucalyptus citriodora essential oils and Perland Pharmacos LTDA (Cornelio Procópio, PR, Brazil) for providing Trihydral dentifrice.

Conflicts of Interest: The authors declare no conflict of interest. The funders had no role in the design of the study; in the collection, analyses, or interpretation of data; in the writing of the manuscript, or in the decision to publish the results.

\section{References}

1. Coulthwaite, L.; Verran, J. Potential pathogenic aspects of denture plaque. Br. J. Biomed. Sci. 2007, 4, 180-189. [CrossRef]

2. Andrucioli, M.C.; Macedo, L.D.; Panzeri, H.; Lara, E.H.G.; Paranhos, H.F.O. Comparison of two cleansing pastes for the removal of biofilm from dentures and palatal lesions in patients with atrophic chronic candidiasis. Braz. Dent. J. 2004, 15, 220-224. [CrossRef]

3. Paranhos, H.F.; Silva-Lovato, C.H.; Souza, R.F.; Cruz, P.C.; Freitas, K.M.; Peracini, A. Effects of mechanical and chemical methods on denture biofilm accumulation. J. Oral Rehabil. 2007, 8, 606-612. [CrossRef]

4. Andrade, I.M.; Silva-Lovato, C.H.; Souza, R.F.; Pisani, M.X.; Andrade, K.M.; Paranhos, H.F.O. Trial of experimental toothpastes regarding quality for cleaning dentures. Int. J. Prosthodont. 2012, 25, 157-159. [PubMed]

5. Paranhos, H.F.O.; Salles, A.E.; Macedo, L.D.; Silva-Lovato, C.H.; Pagnano, V.O.; Watanabe, E. Complete denture biofilm after brushing with specific denture paste, neutral soap and artificial saliva. Braz. Dent. J. 2013, 24, 47-52. [CrossRef] [PubMed]

6. Axe, A.S.; Varghese, R.; Bosma, M.; Kitson, N.; Bradshaw, D.J. Dental health professional recommendation and consumer habits in denture cleansing. J. Prosthet. Dent. 2016, 115, 183-188. [CrossRef]

7. Papadiochou, S.; Polyzois, G. Hygiene practices in removable prosthodontics: A systematic review. Int. J. Dent. Hyg. 2017, 16, 179-201. [CrossRef] [PubMed]

8. Freitas, K.M.; Paranhos, H.F. Weight loss of five commercially available denture teeth after toothbrushing with three different dentifrices. J. Appl. Oral Sci. 2006, 14, 242-246. [CrossRef] [PubMed]

9. Freitas-Pontes, K.M.; Silva-Lovato, C.H.; Paranhos, H.F.O. Mass loss of four commercially available heat-polymerized acrylic resins after toothbrushing with three different dentifrices. J. Appl. Oral Sci. 2009, 17, 116-121. [CrossRef]

10. Pisani, M.X.; Bruhn, J.P.; Paranhos, H.F.; Silva-Lovato, C.H.; Souza, R.F.; Panzeri, H. Evaluation of the abrasiveness of dentifrices for complete dentures. J. Prosthodont. 2010, 19, 369-373. [CrossRef]

11. Sorgini, D.B.; Silva-Lovato, C.H.; Souza, R.F.; Davi, L.R.; Paranhos, H.F.O. Abrasiveness of conventional and specific denturecleansing dentifrices. Braz. Dent. J. 2012, 23, 154-159. [CrossRef] 
12. Roselino, R.M.L.; Alandia-Roman, A.R.; Leite, V.M.F.; Silva-Lovato, C.H.; Pires-de-Souza, F.C.P. Color stability and surface roughness of artificial teeth brushed with an experimental Ricinus communis toothpaste. Braz. J. Oral Sci. 2015, 14, $267-271$. [CrossRef]

13. Sorgini, D.B.; Silva-Lovato, C.H.; Muglia, V.A.; Souza, R.F.; Arruda, C.N.F.; Paranhos, H.F.O. Adverse effects on PMMA caused by mechanical and combined methods of denture cleansing. Braz. Dent. J. 2015, 26, 292-296. [CrossRef]

14. Badaró, M.M.; Salles, M.M.; Arruda, C.N.F.; Oliveira, V.C.; Souza, R.F.; Paranhos, H.F.O.; Silva-Lovato, C.H. In vitro analysis of surface roughness of acrylic resin exposed to the combined hygiene method of brushing and immersion in Ricinus communis and sodium hypochlorite. J. Prosthodont. 2016, 26, 516-521. [CrossRef] [PubMed]

15. Badaró, M.M.; Prates, T.P.; Leite-Fernandes, V.M.F.; Oliveira, V.C.; Paranhos, H.F.O.; Silva-Lovato, C.H. In vitro evaluation of resilient liner after brushing with conventional and experimental Ricinus communis-based dentifrices. J. Prosthodont. 2019, 28, 857-862. [CrossRef] [PubMed]

16. Paranhos, H.F.O.; Panzeri, H.; Lara, E.H.; Candido, R.C.; Ito, I.Y. Capacity of denture plaque/biofilm removal and antimicrobial action of a new denture paste. Braz. Dent. J. 2000, 11, 97-104.

17. Panzeri, H.; Lara, E.H.; Paranhos, H.F.O.; Lovato-Silva, C.H.; Souza, R.F.; Gugelmin, M.C.M.S.; Tirapelli, C.; Criz, P.C.; Andrade, I.M. In vitro and clinical evaluation of specific dentifrices for complete denture hygiene. Gerodontology 2009, 26, 26-33. [CrossRef]

18. Tirapelli, C.; Landi, F.; Ribas, J.; Panzeri, H.; Lara, E.H. Evaluating an experimental dentifrice containing chloramine-T: A preliminary study. Oral Health Prev. Dent. 2010, 8, 375-381.

19. André, R.F.G.; Andrade, I.M.; Silva-Lovato, C.H.; Paranhos, H.F.O.; Pimenta, F.C.; Ito, I.Y. Prevalence of mutans streptococci isolated from complete dentures and their susceptibility to mouthrinses. Braz. Dent. J. 2011, 22, 62-67. [CrossRef]

20. Leite, V.M.F.; Pinheiro, J.B.; Pisani, M.X.; Watanabe, E.; Souza, R.F.; Paranhos, H.F.O.; Silva-Lovato, C.H. In Vitro Antimicrobial activity of an experimental dentifrice based on Ricinus communis. Braz. Dent. J. 2014, 25, 191-196. [CrossRef]

21. Badaró, M.M.; Fernandes, V.M.F.L.; Martin, L.T.; Oliveira, V.C.; Watanabe, E.; Paranhos, H.F.O.; Silva-Lovato, C.H. Antibiofilm activity of an experimental Ricinus communis dentifrice on soft denture liners. Braz. Dent. J. 2019, 30, 252-258. [CrossRef]

22. Carvalho, I.O.; Purgato, G.A.; Píccolo, M.S.; Pizziolo, V.R.; Coelho, R.F.; Diaz-Muñoz, G.; Diaz, M.A.N. In vitro anticariogenic and antibiofilm activities of toothpastes formulated with essential oils. Arch. Oral Biol. 2020, 117, 1-8. [CrossRef]

23. Shaheen, S.S.; Reddy, P.; Hemalatha, S.R.; Doshi, D.; Kulkarni, S.; Kumar, M. Antimicrobial efficacy of ten commercially available herbal dentifrices against specific oral microflora-In vitro study. J. Clin. Diagn. Res. 2015, 9, 42-46. [CrossRef] [PubMed]

24. Casarin, M.; Pazinatto, J.; Santos, R.C.V.; Zanatta, F.B. Melaleuca alternifolia and its application against dental plaque and periodontal diseases: A systematic review. Phytother. Res. 2017, 32, 230-242. [CrossRef]

25. Koseki, Y.; Tanaka, R.; Murata, H. Development of antibacterial denture cleaner for brushing containing tea tree and lemongrass essential oils. Dent. Mater. J. 2018, 37, 659-666. [CrossRef] [PubMed]

26. Rangrej, U.H.; Dave, D.; Saraiva, K. Clinical effect of commercially available two herbal dentifrices on the control of plaque and gingivitis. Inter. J. Sci. Res. 2018, 7, 39-41. [CrossRef]

27. Varma, S.R.; Sherif, H.; Serafi, A.; Fanas, S.A.; Desai, V.; Abuhijleh, E. The antiplaque efficacy of two herbal-based toothpastes: A clinical intervention. J. Int. Soc. Prev. Community Dent. 2018, 8, 21-27. [CrossRef]

28. Mordenti, J.J.; Lindstrom, R.E.; Tanzer, J.M. Activity of sodium ricinoleate against in vitro plaque. J. Pharm. Sci. 1982, 71, 1419-1421. [CrossRef] [PubMed]

29. Baranowska, M.K.; Mardarowicz, M.; Wiwart, M.; Pobłocka, L.; Dynowska, M. Antifungal activity of the essential oils from some species of the genus Pinus. Z Naturforsch C J Biosci. 2002, 57, 478-482. [CrossRef]

30. Carson, C.F.; Hammer, K.A.; Riley, T.V. Melaleuca alternifolia (Tea Tree) oil: A review of antimicrobial and other medicinal properties. Microbiol. Rev. 2006, 19, 50-56. [CrossRef] [PubMed]

31. Luqman, S.; Dwivedi, G.R.; Darokar, M.P.; Kalra, A.; Khanuja, S.P.S. Antimicrobial activity of Eucalyptus citriodora essential oil. Inter. J. Es. Oil Therap. 2008, 2, 69-75.

32. Rodrigues, M.O.; Alves, P.B.; Nogueira, P.C.L.; Machado, S.M.F.; Moraes, V.R.S.; Ribeiro, A.S.; Silva, E.S.; Feitosa, J.G.R. Volatile constituents and antibacterial activity from seeds of Bowdichia virgilioides Kunt. J. Es. Oil Res. 2009, 21, 286-288. [CrossRef]

33. Moghadamtousi, S.Z.; Kadir, H.A.; Hassandarvish, P.; Tajik, H.; Abubakar, S.; Zandi, K. A review on antibacterial, antiviral, and antifungal activity of curcumin. BioMed Res. Int. 2014, 2014, 1-12. [CrossRef]

34. Diefenbach, A.L.; Muniz, F.W.M.G.; Oballe, H.J.R.; Rösing, C.K. Antimicrobial activity of copaiba oil (Copaifera ssp.) on oral pathogens: Systematic review. Phytother. Res. 2018, 32, 586-596. [CrossRef] [PubMed]

35. Kraivaphan, P.; Amornchat, C. Effect of an essential oil-containing dentifrice on established plaque and gingivitis. South. East. Asian J. Trop. Med. Public Health 2012, 43, 243-248.

36. Kulak, Y.; Arikan, A.; Kazazoglu, E. Existence of Candida albicans and microorganisms in denture stomatitis patients. J. Oral Rehabil. 1997, 24, 788-790. [CrossRef] [PubMed]

37. Baena Monroy, T.; Moreno Maldonado, V.; Martinez, F.F.; Barrios, A.B.; Quindos, G.; Sanchez Vargas, L.O. Candida albicans, Staphylococcus aureus and Streptococcus mutans colonization in patients wearing dental prosthesis. Medicina Oral Patologia Oral Cirugia Bucal 2005, 10, 27-39.

38. Campos, M.S.; Marchini, L.; Bernardes, L.A.S.; Paulino, L.C.; Nobrega, F.G. Biofilm microbial communities of denture stomatitis. Oral Microbiol. Immunol. 2008, 5, 419-424. [CrossRef] 
39. Ganesh, S.; Gujjari, A.K.; Shylesh, K.B.S.; Ravi, M.B.; Sowmya, S.; Meenakshi, S. Comparative study to assess the effectiveness of various disinfectants on two microorganisms and the effect of same on flexural strength of acrylic denture base resin-An in vitro study. J. Int. Oral Health 2013, 5, 55-62. [PubMed]

40. Badaró, M.M.; Salles, M.M.; Leite, V.M.F.; Arruda, C.N.F.; Oliveira, V.C.; Nascimento, C.; de Souza, R.F.; Paranhos, H.d.F.d.O.; Silva-Lovato, C.H. Clinical trial for evaluation of Ricinus communis and sodium hypochlorite as denture cleanser. J. Appl. Oral Sci. 2017, 25, 324-334. [CrossRef] [PubMed]

41. Andonissamy, L.; Karthigeyan, S.; Ali, S.A.; Felix, J.W. Effect of chemical denture disinfectants and tree extracts on biofilm-forming Staphylococcus aureus and viridans Streptococcus species isolated from complete denture. J. Contemp. Dent. Prac. 2019, 20, 1307-1314. [CrossRef]

42. International Organization for Standardization. Dental Materials—Guidance on Testing of Wear Resistance-Part 1: Wear by Tooth Brushing; ISO: Geneva, Switzerland, 1999.

43. Nascimento, P.F.C.; Nascimento, A.C.; Rodrigues, S.; Antoniolli, A.R.; Santos, P.O.; Barbosa Júnior, A.M.; Trindade, R.C. Antimicrobial activity of the essentials oils: A multifactor approach of the methods. Rev. Bras. Farmacogn. 2007, 17, 108-113. [CrossRef]

44. Gendreau, L.; Loewy, Z.G. Epidemiology and etiology of denture stomatitis. J. Prosthodont. 2011, 20, 251-260. [CrossRef] [PubMed]

45. Ghannoum, M.A.; Jurevic, R.J.; Mukherjee, P.K.; Cui, F.; Sikaroodi, M.; Naqvi, A.; Gillevet, P.M. Characterization of the oral fungal microbiome (mycobiome) in healthy individuals. PLoS Pathog. 2010, 6, e1000713. [CrossRef]

46. Prakash, B.; Shekar, M.; Maiti, B.; Karunasagar, I.; Padiyath, S. Prevalence of Candida spp. among healthy denture and nondenture wearers with respect to hygiene and age. J. Indian Prosthodont. Soc. 2015, 15, 29-32. [CrossRef]

47. Vanden, A.A.; de Meel, H.; Ahariz, M.; Perraudin, J.P.; Beyer, I.; Courtois, P. Denture contamination by yeasts in the elderly. Gerodontology 2008, 25, 222-228. [CrossRef]

48. Zomorodian, K.; Haghighi, N.N.; Rajaee, N.; Pakshir, K.; Tarazooie, B.; Vojdani, M.; Sedaghat, F.; Vosoghi, M. Assessment of Candida species colonization and denture related stomatitis in complete denture wearers. Med. Mycol. 2011, 49, $208-211$. [CrossRef]

49. Ribeiro, D.G.; Pavarina, A.C.; Dovigo, L.N.; Machado, A.L.; Giampaolo, E.T.; Vergani, C.E. Prevalence of Candida spp. associated with bacteria species on complete dentures. Gerodontology 2012, 29, 203-208. [CrossRef]

50. Daef, E.; Moharram, A.; Eldin, S.S.; Elsherbiny, N.; Mohammed, M. Evaluation of chromogenic media and seminested PCR in the identification of Candida species. Braz. J. Microbiol. 2014, 45, 255-262. [CrossRef]

51. Glass, R.T.; Bullard, J.W.; Conrad, R.S.; Blewett, E.L. Evaluation of the sanitization effectiveness of a denture-cleaning product on dentures contaminated with known microbial flora. An in vitro study. Quintessence Int. 2004, 35, 194-199.

52. Thein, Z.N.; Samaranayake, Y.H.; Samaranayake, L.P. Effect of oral bacteria on growth and survival of Candida albicans biofilms. Arch. Oral Biol. 2001, 51, 672-680. [CrossRef]

53. Glasse, R.T.; Bullard, J.W.; Hadley, C.S.; Mix, E.W.; Conrad, R.S. Partial spectrum of microorganisms found in dentures and possible disease implications. J. Am. Osteopath. Assoc. 2001, 101, 92-94. [CrossRef]

54. Coenye, T.; De Prijck, K.; De Wever, B.; Nelis, H.J. Use of the modified Robbins device to study the in vitro biofilm removal efficacy of NitrAdine, a novel disinfecting formula for the maintenance of oral medical devices. J. Appl. Microbiol. 2008, 105, 733-740. [CrossRef]

55. Smith, A.J.; Jackson, M.S.; Bagg, J. The ecology of Staphylococcus species in the oral cavity. J. Med. Microbiol. 2001, 50, 940-946. [CrossRef]

56. Albuquerque Jr., R.; Head, T.W.; Mian, H.; Ridrigo, A.; Müller, K.; Sanches, K.; Ito, I.Y. Reduction of salivar S. aureus and mutans group streptococci by a preprocedural chlorhexidine rinse and maximal inhibitory dilutions of chlorhexidine and cetylpyridinium. Quintenssence Int. 2004, 35, 635-640.

57. Macià, M.D.; Rojo-Molinero, E.; Oliver, A. Antimicrobial susceptibility testing in biofilm-growing bacteria. Clin. Microbiol. Infect. 2014, 20, 981-990. [CrossRef]

58. Paranhos, H.F.O.; Silva-Lovato, C.H.; Souza, R.F.; Cruz, P.C.; Pontes, K.M.F.; Watanabe, E.; Ito, I.Y. Effect of three methods for cleaning dentures on biofilm formed in vitro on acrylic resin. J. Prosthod. 2009, 18, 427-431. [CrossRef]

59. Peters, B.M.; Jabra-Rizk, M.A.; Scheper, M.A.; Leid, J.G.; Costerton, J.W.; Shirtliff, M.E. Microbial interactions and differential protein expression in Staphylococcus aureus—Candida albicans dual-Species biofilms. FEMS Immunol. Med. Microbiol. 2010, 59, 493-503. [CrossRef] [PubMed]

60. Coimbra, F.C.T.; Salles, M.M.; Oliveira, V.C.; Macedo, A.P.; Silva-Lovato, C.H.; Pagnano, V.O.; Paranhos, H.F.O. Antimicrobial efficacy of complete denture cleansers. Am. J. Dent. 2016, 29, 149-153. [PubMed]

61. Paranhos, H.F.O.; Coimbra, F.C.T.; Salles, M.M.; Oliveira, V.C.; Macedo, A.P.; Pagnano, V.O.; Silva-Lovato, C.H. In vitro evaluation of the effectiveness of alkaline peroxide solutions in reducing the viability of specific biofilms. Am. J. Dent. 2019, 32, 201-206. [PubMed]

62. Coimbra, F.C.T.; Rocha, M.M.; Oliveira, V.C.; Macedo, A.P.; Pagnano, V.O.; Silva-Lovato, C.H.; Paranhos, H.F.O. Antimicrobial activity of effervescent denture tablets on multispecies biofilms. Gerodontology 2021, 1, 87-94. [CrossRef] [PubMed]

63. Tobouti, P.L.; Mussi, M.C.M.; Rossi, D.C.P.; Pigatti, F.M.; Taborda, C.P.; Taveira, L.A.A.; Sousa, S.C.O.M. Influence of Melaleuca and Copaiba oils on Candida albicans adhesion. Gerodontology 2014, 33, 380-385. [CrossRef] [PubMed] 
64. Alencar, E.N.; Xavier-Junior, F.H.; Morais, A.R.; Dantas, T.R.; Dantas-Santos, N.; Verissimo, L.M.; Rehder, V.L.G.; Chaves, G.M.; Oliveira, A.G.; Egito, E.S.T. Chemical characterization and antimicrobial activity evaluation of natural oil nanostructured emulsions. J. Nanosci. Nanotechnol. 2015, 15, 880-888. [CrossRef] [PubMed]

65. Vasconcelos, K.R.; Veiga Júnior, V.F.; Rocha, W.C.; Bandeira, M.F. In vitro assessment of antibacterial activity of a dental cement constituted of a Copaifera multijuga Hayne oil-resin. Rev. Bras. Farmacogn. 2008, 18, 33-38. [CrossRef]

66. Moo, C.L.; Yang, S.K.; Osman, M.A.; Yuswan, M.H.; Loh, J.Y.; Lim, W.M.; Lim, S.H.; Lai, K.S. Antibacterial activity and mode of action of beta-caryophyllene on Bacillus cereus. Pol. J. Microbiol. 2020, 69, 1-6. [CrossRef]

67. Ramezani, H.; Singh, H.P.; Batish, D.R.; Kohli, R.K. Antifungal activity of the volatile oil of Eucalyptus citriodora. Fitoterapia 2002, 73, 261-262. [CrossRef]

68. Tolbaa, H.H.; Moghrania, A.; Mouffok, D.B.; Maachia, R.K. Essential oil of algerian Eucalyptus citriodora: Chemical composition, antifungal activity. J. Mycol. Med. 2015, 25, 128-133. [CrossRef]

69. Hans, V.M.; Grover, H.S.; Deswal, H.; Agarwal, P. Antimicrobial efficacy of various essential oils at varying concentrations against periopathogen Porphyromonas Gingivalis. J. Clin. Diagn Res. 2016, 10, 16-19. [CrossRef]

70. Zengin, H.; Baysal, A.H. Antibacterial and antioxidant activity of essential oil terpenes against pathogenic and spoilage-forming bacteria and cell structure-activity relationships evaluated by SEM microscopy. Molecules 2014, 19, 17773-17798. [CrossRef]

71. Yu, D.; Wang, J.; Shao, X.; Xu, F.; Wang, H. Antifungal modes of action of tea tree oil and its two characteristic components against Botrytis cinerea. J. Appl. Microbiol. 2015, 119, 1253-1262. [CrossRef]

72. Worbs, S.; Köhler, K.; Pauly, D.; Avondet, M.A.; Schaer, M.; Dorner, M.B.; Dorner, B.G. Ricinus communis intoxications in human and veterinary medicine-a summary of real cases. Toxins 2011, 3, 1332-1372. [CrossRef]

73. Rivas da Silva, A.C.; Lopes, P.M.; Barros de Azevedo, M.M.; Costa, D.C.; Alviano, C.S.; Alviano, D.S. Biological activities of $\alpha$-pinene and $\beta$-pinene enantiomers. Molecules 2012, 17, 6305-6316. [CrossRef] [PubMed]

74. Clinical and Laboratory Standards Institute/National Comitee for Clinical Laboratory Standards (CLSI/NCCLS). Performance Standards for Antimicrobial Susceptibility Testing: Twenty-Third Informational CLSI/NCCLS Document; Clinical and Laboratory Standards Institute: Wayne, PA, USA, 2013; pp. 100-123.

75. Aligiannis, N.; Kalpoutzakis, E.; Mitaku, S.; Chinou, I.B. Composition and antimicrobial activity of the essential oil of two Origanum species. J. Agri. Food Chem. 2001, 40, 4168-4170. [CrossRef] [PubMed]

76. Karygianni, L.; Al-Ahmad, A.; Argyropoulou, A.; Hellwig, E.; Anderson, A.C.; Skaltsounis, A.L. natural antimicrobials and oral microorganisms: A systematic review on herbal interventions for the eradication of multispecies oral biofilms. Front. Microbiol. 2016, 6, 1529. [CrossRef] [PubMed] 